\title{
TNFSF15 Gene
}

National Cancer Institute

\section{Source}

National Cancer Institute. TNFSF15 Gene. NCI Thesaurus. Code C21113.

This gene plays an inhibitory role in angiogenesis regulation. 